\title{
BIOLOGICAL AND HEMATOLOGICAL RESPONSES OF BIOMPHALARIA ALEXANDRINA TO MYCOBIOSYNTHSIS SILVER NANOPARTICLES
}

\author{
By \\ HODA ABDEL-HAMID ${ }^{1}$ AND AMAL A.I. MEKAWEY ${ }^{2}$ \\ Department OF Environmental Researches and Medical Malacology ${ }^{1}$, Theodor \\ Bilharz Research Institute and Regional Center for Mycology and \\ Biotechnology ${ }^{2}$, Al-Azhar University, Cairo, Egypt.
}

\begin{abstract}
Silver nanoparticles (AgPNs) extracts were prepared from seven Seven fungal isolates were evaluated through measuring their toxicity against Biomphalaria alexandrina snails. The effects of the two promising Paecilomyces variotii and Aspergillus niger AgNPs sublethal concentrations $\left(\mathrm{LC}_{10} \& \mathrm{LC}_{25}\right)$ on the levels of steroid sex hormones, liver enzymes, total protein, lipids, albumin, glucose, total and differential count of hemocytes and morphology of hemocytes, oocytes and sperms were studied in this work.

The short period of snails' exposure (24h) to the two fungal AgNPs resulted in significant decrease in the levels of progesterone in B. alexandrina. The level of testosterone hormone showed significant increase in snails exposed to $P$. variotii AgNPs while no significant change was recorded at the exposure to A. niger AgNPs. Also, estradiol hormone concentration increased significantly in this investigation with the increase of the concentration of the two tested compounds. In addition, significant elevation in ALT, AST and Alkaline phosphatase was recorded. The total number of the hematocytes increased significantly by $17.4-47.8 \%$. Snails' granulocytes were reduced by $19.1-43.8 \%$, while hyalinocytes increased by $63.6-354.5 \%$. The exposure of $B$. alexandrina to $\mathrm{LC}_{25}$ of both $P$. variotii and $A$. niger AgNPs showed apoptotic hemolymph cells, fragmented, vacuolated and degenerated cytoplasm, shrunken nucleus and phagocytosis in the light microscopy photographs of the hemocytes. Besides, the photographs showed also, abnormal nuclear division, degeneration and large fat vacuoles in the cytoplasm and swallowed atretic oocytes. Also, the photographs showed dead sperm head separated from its tail, other sperms showed abnormal swallowed head with severely nodded tail, dead sperms with wrinkled tails, hyperplasia and necrotic sperm heads led to overlapping of tails. In conclusion, applying the biosynthesized compounds which led to destruction of blood cells (the immune system), ova and sperms (the reproductive system) of snails is an important effective step to control schistosomiasis.
\end{abstract}

Key words: Biomphalaria alexandrina, Paecilomyces variotii, Aspergillus niger, AgNPs, steroid hormones, granulocytes, hyalinocytes, schistosomiasis.

\section{Introduction}

There are multiple parameters affecting the transmission of schistosomiasis as water related vector-borne disease. Among them, the life expectancy of the snail intermediate hosts, in which schistosome larvae undergo asexual reproduction and developed to the human infecting stage "cercariae" (Anderson and May, 1985). Snail control could be regarded as a rapid and efficient of re- ducing or eliminating transmission and remains among the methods of choice for schistosomiasis control (Rizk et al., 2012). A new approach to control the vector snails of schistosomiasis; $B i$ omphalaria alexandrina is the using of nanoparticles (El-Hommossany and ElSherbibni, 2011).

On the other hand, chemical and physical methods have various limitations in terms of synthesis procedures which 
may involve use of drastic experimental conditions coupled with release of toxic byproducts, thus damaging the environment. An alternative approach is their production by the process of mycosynthesis, using different species of fungi which act as nanobiofactories, since they produce and secrete enzymes which help in reduction of metal ions to nanoparticles. They are further easy to culture, maintain and due to considerable biomass favor the large scale production of a wide variety of metal nanoparticles including those of silver, gold, iron, cadmium, selenium and platinum. They have been found to possess monodispersity, stability and other favorable properties which have led to their wide usage and applications. However, biological methods, which make use of fungi, bacteria and plants, are more ecofriendly and are being explored as alternatives to conventional techniques which invariably involve hazardous waste generation (Das \& Thiagarajan, 2012).

The fungus Aspergillus fumigatus (Sastry et al., 2003) fungus resulted in the rapid synthesis of silver nanoparticles and the particles formed were monodisperse which can be used in bacterial applications. Aspergillus flavus (Mahendra et al., 2009) also resulted in the accumulation of silver nanoparticles on the surface of its cell wall when incubated with silver nitrate solution.

Circulating hemocytes represent the primary mediator of cellular defense reactions in molluscs. Hemocyte morphology is continuously being given importance and several studies have been conducted on snail species (Noda and Loker, 1989; Barraco et al, 1993; Kambale and Potdar, 2010; Di et al, 2011; Cavalcanti et al, 2012). Schistosome vector Snail' elimination could be possible through applying safe biocontrol agents affecting its immunity (Cir- culating hemocytes) and reproduction (oocytes and sperms).

This work was undertaken to evaluate the role of mycobiosynthesis silver nanoparticles against $B$. alexandrina snails and its effects on some snails' hematological and biological parameters. Also, the study aims to test the possibility of using these compounds as a biological control for schistosomiasis vector snails.

\section{Materials and Methods}

Laboratory bred adult Biomphalaria alexandrina snails $(8-10 \mathrm{~mm})$ were obtained from the Medical Malacology Laboratory, Theodor Bilharz Research Institute (TBRI), Giza, Egypt.

Seven fungal isolates: Penicillium aurantiogresium (IMI 89372); P. roqueforti (IMI 285518); Aspergillus niger (NRRL, 595); Verticillium chlamydosporium var. (CBS 600.88); Trichoderma viride (RCMB 004001); $T$. longibranchiatum (RCMB 004006) and Paecilomyces variotii (RCMB 004101) were kindly provided from the culture collection unit of the Regional Center for Mycology and Biotechnology (RCMB) Al-Azhar University, CairoEgypt. All fungal isolates were subcultured and maintained on Sabouraud's Glucose agar (SGA) medium containing $(\mathrm{g} / \mathrm{l})$; glucose-20; peptone-10; agar20 and distilled water, $1000 \mathrm{ml}, \mathrm{pH}$ of medium was adjust to $5.4 \pm 0.2$ at $25 \pm 2^{\circ} \mathrm{C}$.

Previously, all fungal isolates were subjected for the extracellular biosynthesis of AgNPs, studying their optimal condition and characterized using UV-Visible Spectral Analysis, FT-IR, EDX, XRD and TEM analyses in an earlier work (Helmy and Mekawey, 2013).

The seven fungal AgNPs compounds were investigated against $B$. alexandrina snails by the exposure of 10 snails to each compound for $24 \mathrm{~h}$ at $100 \mathrm{ppm}$ concentration. Then they maintained in 
dechlorinated water $24 \mathrm{~h}$ for recovery and the mortality rate for snails was calculated. The promising compounds were chosen to complete the experimental study.

For molluscicidal screening, a stock solution of the tested compounds (1000 $\mathrm{ppm}$ ) was prepared on the basis of $\mathrm{W} / \mathrm{V}$ using dechlorinated tap water $(\mathrm{pH} 7.0$ 7.5). A series of concentrations that would permit the computation of $\mathrm{LC}_{50}$ and $\mathrm{LC}_{90}$ values were prepared from the compound (WHO, 1965). Three replicates were used, each of 10 snails (6-8 $\mathrm{mm}) / \mathrm{L}$ of each concentration. Exposure and recovery periods were $24 \mathrm{~h}$ each at $25 \pm 1^{\circ} \mathrm{C}$. For each test, three replicates of control snails were maintained under the same experimental conditions. The effectiveness for each compound has been expressed in terms of $\mathrm{LC}_{50}$ and $\mathrm{LC}_{90}$.

B. alexandrina snails exposed 24 hours to the sublethal concentrations $\left(\mathrm{LC}_{10}\right.$ and $\mathrm{LC}_{25}$ ) of the promising fungal silver nanoparticles compounds in all experiments.

For hemolymph collection, the snails were dried by a paper towel and placed on their left side (i.e. spiral clockwise) on the bottom of a dry Petri dish. A small portion of the shell situated directly above the heart was removed and a syringe was inserted into the heart to collect the hemolymph as described by Negm et al. (1995).

The levels of total protein (Domas, 1975), albumin (Gustafsson, 1976), glucose (Trinder, 1969) and lipids concentrations (Knight et al, 1972) were determined in the collected hemolymph. Also, the activities of transaminases Aspartate (AST) and alanine aminotreansferase (ALT) (Reitman and Frankel, 1957; White et al, 1970), the phosphatases; acid phosphatase; AcP (Moss, 1984) and alkaline phosphatase; AkP
(Babson, 1965) enzymes in the hemolymph of $B$. alexandrina snails were detected. Tested biochemical parameters were evaluated spectrophotometrically by using kits from Quimica Clinica Aplicada S. A. (QCA) Ltd., Span.

The concentrations of progesterone, Testosterone and Estradiol hormones were also determined by gas-liquid chromatography according the method of La atikainen et al. (1973).

For total and differential counting, monolayer of hemocytes were stained with Giemsa stain for 20 minutes, according to the methods of Abdul-Salam and Michelson (1983), examined and counted by light microscopy and photographed by Toup View Camera. Another sample for each group was withdrawn from the region of the hermaphrodite gland (after gentle crushing) and stained as previously mentioned for the examination of ova and sperms.

Statistical analysis was performed by the SPSS computer program (version 20 for windows).

\section{Results}

The silver nanoparticles (AgNPs) of Penicillium aurantiogresium (IMI 89372); P. roqueforti (IMI 285518); Aspergillus niger (NRRL 595); Verticillium chlamydosporium var. (CBS 600.88); Trichoderma viride (RCMB 004001); T. longibranchiatum (RCMB 004006) and Paecilomyces variotii (RCMB 004101) were investigated for their molluscicidal activity against Schistosoma mansoni vector snails (Biomphalaria alexandrina). Table (1) revealed that the AgNPs of two fungi only (Paecilomyces variotii and Aspergillus niger) have molluscicidal activity (85 and 95\% mortality) at concentration of 100 ppm when exposed 24 hours and recovered for another day. 
Table 1: Molluscicidal effect of fungal AgNPs against B. alexandrina after exposure to 100 ppm for 24 hours.

\begin{tabular}{|l|c|}
\hline \multicolumn{1}{|c|}{ Fungal AgNPs } & Snails' mortality \% \\
\hline Penicillium aurantiogresium & 0 \\
\hline Penicillium roqueforti & 0 \\
\hline Verticillium chlamydosporium & 0 \\
\hline Trichoderma viride & 0 \\
\hline Trichoderma longibranchiatum & 85 \\
\hline Paecilomyces variotii & 95 \\
\hline Aspergillus niger & \\
\hline
\end{tabular}

Molluscicidal activity of silver nanoparticles of the two promising fungal AgNPs (Paecilomyces variotii and Aspergillus niger) against $B$. alexandrina snails after 24 hours of exposure and

Table 2: Molluscicidial activity of Paecilomyces variotii and Aspergillus niger AgNPs against adult B. alexandrina (24 hours exposure).

\begin{tabular}{|c|c|c|c|c|c|}
\hline & $\mathrm{LC}_{10}$ & $\mathrm{LC}_{25}$ & $\mathrm{LC}_{50}$ & $\mathrm{LC}_{90}$ & SLOPE \\
\hline Paecilomyces variotii AgNPs & 65.5 & 74.7 & 85.0 & 104.5 & 1.21 \\
\hline Aspergillus niger AgNPs & 32.6 & 47.9 & 64.8 & 97.0 & 1.54 \\
\hline
\end{tabular}

Regarding biochemical analysis (Tab. 4) the exposure to the tested compounds led to disturbance in the levels of the steroid hormones in B. alexandrina hemolymph. The progesterone levels decreased significantly, while the levels of testosterone and estradiol increased. $A$. niger AgNPs did not affect the testosterone hormone. The liver enzymes (ALT \&AST) increased significantly by other $24 \mathrm{~h}$ recovery (Tab. 2). Data obtained indicated that $A$. niger AgNPs is more toxic to $B$. alexandrina than $P$. variotii AgNPs.

Table 3: Effect of Paecilomyces variotii and Aspergillus niger AgNPs sublethal concentrations on some biochemical parameters and steroid hormones of $B$. alexandrina after $24 \mathrm{~h}$ exposure.

\begin{tabular}{|c|c|c|c|c|c|c|c|c|c|c|}
\hline \multirow{3}{*}{ Test } & \multirow{2}{*}{\multicolumn{2}{|c|}{ Control }} & \multicolumn{4}{|c|}{ P. variotii AgNPs } & \multicolumn{4}{|c|}{ A. niger AgNPs } \\
\hline & & & \multicolumn{2}{|c|}{$\begin{array}{c}\mathrm{LC}_{10} \\
(65.5 \mathrm{ppm})\end{array}$} & \multicolumn{2}{|c|}{$\begin{array}{c}\mathrm{LC}_{25} \\
(74.7 \mathrm{ppm})\end{array}$} & \multicolumn{2}{|c|}{$\begin{array}{c}\mathrm{LC}_{10} \\
(32.6 \mathrm{ppm})\end{array}$} & \multicolumn{2}{|c|}{$\begin{array}{c}\mathrm{LC}_{25} \\
(47.9 \mathrm{ppm})\end{array}$} \\
\hline & Mean & SD & Mean & SD & Mean & SD & Mean & SD & Mean & SD \\
\hline Progesterone $(\mathrm{Nmol} / \mathrm{L})$ & 0.51 & 0.05 & $0.37 *$ & 0.03 & $0.39 *$ & 0.04 & $0.36 *$ & 0.03 & $0.31 * *$ & 0.04 \\
\hline Testosterone (Nmol/L) & 0.46 & 0.04 & $1.55 * * *$ & 0.07 & $1.33 * * *$ & 0.06 & $0.41 \mathrm{~ns}$ & 0.02 & $0.52 \mathrm{~ns}$ & 0.05 \\
\hline Estradiol $(\mathrm{Pg} / \mathrm{ml})$ & 23.9 & 3.50 & $33.1 *$ & 3.81 & $36.1^{* *}$ & 2.67 & $41.6^{* *}$ & 4.11 & $42.8 * *$ & 3.08 \\
\hline $\operatorname{ALT}(\mathrm{U} / \mathrm{ml})$ & 179 & 9.01 & $183^{\mathrm{ns}}$ & 6.23 & $423 * * *$ & 11.08 & $201 *$ & 9.88 & $280 * * *$ & 4.46 \\
\hline $\operatorname{AST}(\mathrm{U} / \mathrm{ml})$ & 80 & 5.31 & $214 * * *$ & 7.67 & $235 * * *$ & 8.09 & $212 * * *$ & 6.33 & $747 * * *$ & 13.04 \\
\hline Alkaline phosphatase(U/L) & 84 & 7.02 & $108 *$ & 9.11 & $181 * * *$ & 5.32 & $317 * * *$ & 7.91 & $410 * * *$ & 9.54 \\
\hline Acid phosphatase (U/ml) & 0.08 & 0.02 & $0.06 \mathrm{~ns}$ & 0.01 & 0.05 & 0.03 & $0.07^{\mathrm{ns}}$ & 0.02 & $0.06^{\mathrm{ns}}$ & 0.04 \\
\hline Total protein $(\mathrm{mg} / 100 \mathrm{ml})$ & 2.84 & 0.82 & $3.1 \mathrm{~ns}$ & 0.67 & $3.4 \mathrm{~ns}$ & 0.35 & $3.45^{\mathrm{ns}}$ & 0.79 & $2.7^{\mathrm{ns}}$ & 0.56 \\
\hline Glucose $(\mathrm{mg} / 100 \mathrm{ml})$ & 31.9 & 4.51 & $30.6 \mathrm{~ns}$ & 6.11 & $35.3 \mathrm{~ns}$ & 5.53 & $33.6 \mathrm{~ns}$ & 8.01 & $35.8^{\mathrm{ns}}$ & 7.09 \\
\hline Albumin (g/l) & 1.8 & 0.80 & $1.9 \mathrm{~ns}$ & 0.09 & $1.8 \mathrm{~ns}$ & 0.51 & $1.7 \mathrm{~ns}$ & 0.46 & $2.0^{\mathrm{ns}}$ & 0.08 \\
\hline Total lipids $(\mathrm{mg} / 100 \mathrm{ml})$ & 352.6 & 15.38 & $375.6 \mathrm{~ns}$ & 13.44 & 352.1 & 9.78 & 321.1 & 14.11 & $322.7^{\mathrm{ns}}$ & 14.47 \\
\hline
\end{tabular}

$*, * * \& * * *=$ significantly different from control at $\mathrm{p}<0.05, \mathrm{p}<0.01 \& \mathrm{p}<0.001, \mathrm{~ns}=$ no significant difference $(\mathrm{p}>0.05)$.

In hematological study, total count of the hemocytes showed significantly in-

crease by $17.4-47.8 \%$ in the snails exposed to both $A$. niger AgNPs and $P$. 
variotii AgNPs sublethal concentrations 24 h compared to control ones (Tab. 3). Differential count indicated a significant reduction in the large granulocytes by $44.7 \%$ and $28.9 \%(\mathrm{p}<0.001)$ in snails exposed to $\mathrm{LC}_{25}$ from $A$. niger and $P$. variotii AgNPs, respectively. On the other hand, the hyalinocytes increased significantly in treated groups than the untreated control.

Table 4: Total and differential count of B. alexandrina hemocytes after exposure to Paecilomyces variotii and Aspergillus niger AgNPs for 24 hours.

\begin{tabular}{|l|l|l|l|l|l|}
\hline \multirow{2}{*}{ AgNPs compound } & \multicolumn{2}{|c|}{ Total Count } & \multicolumn{3}{c|}{ Differential count \% } \\
\cline { 2 - 7 } & Mean & SD & LG & SG & Hy \\
\hline Control & 2300 & 101.4 & 76 & 13 & 11 \\
\hline$P$. variotii $\left(\mathrm{LC}_{10}\right)$ & $2700^{*}$ & 165.7 & $62 *$ & $10 \mathrm{~ns}$ & $18 \mathrm{~ns}$ \\
\hline P. variotii $\left(\mathrm{LC}_{25}\right)$ & $2900^{*}$ & 202.8 & $42^{* * *}$ & $8 \mathrm{~ns}$ & $50 * * *$ \\
\hline A. niger $\left(\mathrm{LC}_{10}\right)$ & $3200^{* *}$ & 300.0 & $51^{* * *}$ & $6 \mathrm{~ns}$ & $43 * * *$ \\
\hline A. niger $\left(\mathrm{LC}_{25}\right)$ & $3400^{* *}$ & 265.7 & $54 * * *$ & $6 \mathrm{~ns}$ & $40^{* * *}$ \\
\hline
\end{tabular}

$\mathrm{LG}=$ large granulocyte, $\mathrm{SG}=$ small granulocyte, $\mathrm{Hy}=$ Hyalinocyte, $* * * \& * * *=$ significantly different from control at $\mathrm{p}<0.05, \mathrm{p}<0.01 \& \mathrm{p}<0.001, \mathrm{~ns}=$ no significant difference $(\mathrm{p}>0.05)$

The light microscopy photographs of $B$. alexandrina hemocytes (Fig. 1, Control) showed two morphologically distinct types of hemocytes, granulocytes and hyalinocytes. Granulocytes are distinguished to two types, large and small granulocytes with a low nucleus to cytoplasm ratio. Large granulocyte cells (LG) are variable in size with small nucleus and high cytoplasmic content due to the presence of refractile granules. Small granulocytes (SG) are intermediate cells with several micron sized granules and distinguished from LG by the central location of the nucleus and a relatively constant size. The hyalinocyte cells (Hy) are characterized by small size and they are circular shape with clear dense cell membrane, large nucleus and basophilic cytoplasm with a high nucleus to cytoplasm ratio.

B. alexandrina snails exposed to $\mathrm{LC}_{10}$ of $P$. variotii AgNPs for $24 \mathrm{~h}$ showed some abnormalities in LG cells; eccentric nucleus (Fig. 1, A) nucleus division (Fig. 1, B) and the hyalinocytes appeared with vacuolated nucleus. When the concentration increased to $\mathrm{LC}_{25}$, the LG cells showed abnormal dividing with highly vacuolated cytoplasm (Fig. 1, D), cell wall invagination (Fig. 1, E) pseudopodia (Fig. 1, F), vaculated cy- toplasm (Fig. 1, G) and the Hy cells appeared with cytoplasmic vacuoles (Fig. $1, \mathrm{H})$.

The exposure to $\mathrm{LC}_{10}$ of $A$. niger AgNPs for $24 \mathrm{~h}$ showed enlarged dividing LG (Fig. 1, I), phagocytosis (Fig. 1, J) and lysed Hy (Fig. 1, N). When $B$. alexandrina exposed to $\mathrm{LC}_{25}$ of $A$. niger AgNPs, the hemocytes' morphology showed obvious abnormalities. Granulocytes and hyalinocytes showed cell apoptosis with degenerated cytoplasm with released granules and shrinked nucleus (Fig. 1, L- N).

The impact of the tested compounds on the morphology of $B$. alexandrina oocytes and sperms was illustrated in figures $(2 \& 3)$. Figure $(2, \mathrm{~A})$ showed the normal mature oocyte and sperm in control group. B. alexandrina treated with $\mathrm{LC}_{10}$ of $P$. variotii AgNPs showed terminal and divided nuclei (Fig 2, B \& C), sperm head separated from its tail (Fig 2, D) and in Fig $(2$, E) the sperm showed pin head and thickened tail. The exposure to $\mathrm{LC}_{25}$ led to light degeneration of the oocyte contents even in the oocyte division (Fig 2, F \& G), the sperms showed swallowed head and thin tail (Fig 2, H) and other sperms showed abnormal swallowed head with severely nodded tail (Fig 2, I). 
The exposure to $A$. niger AgNPs showed strong toxic effects on the oocytes and sperms of snails. At $\mathrm{LC}_{10}$ exposure, the photographs showed dead aggregated ova (Fig. 3, A), sperms appeared in necklace shape (Fig. 3, B) and other showed swallowing of sperms heads. Increasing the concentration to $\mathrm{LC}_{25}$ led to the appearance of swallowed, vacuolated and degenerated ova (Fig. 3, D), also other oocytes appeared with large fat vacuoles which led to degeneration of its contents (Fig. 3, E). in addition, the photographs showed atretic oocyte surrounded by dead sperms with wrinkled tails (Fig. 3, F) and hyperplasia and necrotic sperms heads led to overlapping of tails (Fig. 3, G).

\section{Discussion}

The present study results revealed that the silver nanoparticles of two fungi (Paecilomyces variotii and Aspergillus niger) from seven proved to have molluscicidal activity against $B$. alexandrina (at concentration of $100 \mathrm{ppm}$ ) of $85 \%$ and $95 \%$, respectively. Ghoneimy et al. (2014) recorded toxic five fungal strains extracts (Aspergillus sclerotium; Chaetomium globosum; Penicillium canescens; Penicillium griseofulvum and Trichoderma longibrachiatum) from thirty against $B$. alexandrina and Bulinus truncatus snails. These results are also, in parallel with that of ElHommossany and El-Sherbibni (2011) who recorded lethal effect of the photosensitizer Hematoporphyrin coated gold Nanoparticles (Hpd coated GNPs) against $B$. alexandrina .

The present results reported significance decrease in the levels of progesterone in snails treated with the two fungal AgNPs, which may lead to poor reproductive efficiency as a management for control snails' strategy. This agrees with the results of Mohamed and Aly (2014) who found significant low level of progesterone in Fenitrothion treated snails. In addition, the levels of testosterone hormone increased significantly in snails treated with $P$. variotii AgNPs while no significant changes were observed at the exposure to $A$. $n i$ ger AgNPs. This agreed with Rizk et al. (2012) who found disturbance in the level of steroid hormones in B. alexandrina treated with Haplophyllum tuberculatum.

Also, the concentration of estradiol hormone increased significantly in this investigation with the increase of the two fungal AgNPs concentration. The high concentration of estradiol in treated snails may be related to increasing rates of proliferation and protein synthesis that in turn leads to increase in total protein content_as documented in the present results. On the other hand, Mohamed and Aly (2014) found decrease in estradiol hormone and total protein concentrations in Fenitrothion treated snails. The significant elevation in ALT, AST and AkP in treated snails is in agreement with Al-Sayed et al. (2014) who found that AkP and AcP were significantly increased by 38.5 and $48.4 \%$ in the hemolymph of B. alexandrina exposed to $\mathrm{LC}_{25}$ of the methanol extract of E. globulus and M. styphelioides, respectively. In addition, Ghoneimy et al. (2014) found that all the liver enzymes (AST, ALT, AcP and $\mathrm{AkP})$ in the hemolymph of the exposed snails were elevated significantly by the exposure to $\mathrm{LC}_{25}$ of the Penicillium $\mathrm{ca}$ nescens bioactive compound for 4 weeks.

The hemocytes total count of snails exposed to sublethal concentrations of $P$. variotii and $A$. niger AgNPs showed significant increase compared to control group. The elevation of total hemocytes is the most commonly observed response in different molluscan species exposed to different stressors. Russo 
and Lagadic (2004) stated that, the increase in hemocyte density might be seen as a way for the snails to maintain a constant level of global phagocytic activity, which was inhibited as a result of treatment. In agreement with this result, Mohamed (2011), found that exposure of $B$. alexandrina snails to sublethal concentration of Roundup herbicide led to significant increase in total hemocytes counts during 7 days of exposure. Consequently, the spreading hemocytes increased during the whole experimental period.

The present data recorded significant reduction in the number of granulocytes by $19.1-43.8 \%$ and increase in the number of hyalinocytes by $63.6-354.5 \%$ in treated experimental groups. In agreement with these results, Gawish et al. (2008) recorded a reduction by $34.9 \%$ in granulocytes of Bulinus truncatus continuously exposed to $\mathrm{LC}_{10}$ of the Callistemon citrinus extract for one week, while amoebocytes and hyalinocytes were increased by $54.4 \%$ and $21.7 \%$, respectively. Mossallam et al. (2013) found a decrease in the number of $B$. alexandrina hemocytes when exposed continuously to $\mathrm{LC}_{25}$ Artemether. Similar results were found by Sharaf El-Din (2003), Souza and Andrade (2006) and Kamel et al. (2006, 2007).

The light microscopy photographs of untreated $B$. alexandrina hemolymph showed two morphologically distinct types of hemocytes; granulocytes and hyalinocytes. This was agreed with Sminia and Van der Knaap (1987), Lie et al. (1987), Barraco et al. (1993) and Serrano et al. (2002).

The exposure of $B$. alexandrina to $\mathrm{LC}_{25}$ of both $P$. variotii and $A$. niger AgNPs showed apoptotic hemolymph cells, fragmented, vacuolated and degenerated cytoplasm, shrinked nucleus and phagocytosis. Kamel et al. (2007) and Gawish et al. (2008) reported the same results when using different plant molluscicides on hemocyte of $B$. alexandrina and $B$. truncatus. These abnormalities recorded in the hemocytes were also confirmed with the findings of Sharaf El-Din (2003), Souza and Andrade (2006), Kamel et al. (2006) and Mossallam et al. (2013).

Severe abnormalities also were detected in $B$. alexandrina oocytes and sperms due to the toxic effect of $P$. variotii and A. niger AgNPs in the present work. The photographs showed abnormal nuclear division, degeneration and large fat vacuoles in the cytoplasm and swallowed atretic oocytes. Also, the photographs showed dead sperm head separated from its tail, other sperms showed abnormal swallowed head with severely nodded tail, dead sperms with wrinkled tails, hyperplasia and necrotic sperm heads led to overlapping of tails. These abnormalities may be due to the inhibiting action of the fungal AgNPs on oogenesis and spermatogenesis in the ovotestestis gland. These results in agreement with Abdel-Hamid et al. (2014) who recorded ova and sperm abnormalities as a result of $B$. alexandrina and $B$. truncatus exposure to sublethal concentrations of $P$. canescens bioactive compound. Also, Bakry et al. (2002) found that, B. alexandrina snails exposed to fungicide (Isoprothiolane) laid highly significant number of abnormal egg masses. Pagano et al. (2001) showed significant toxicity of R6 fungicide on sea urchins resulting in embryo developmental defects, transmissible damage from sperm to the offspring and cytogenetic abnormalities.

\section{Conclusion}

The applying the biosynthesized compounds which led to destruction of blood cells (the immune system), ova and sperms (the reproductive system) of snails is an important effective step to control schistosomiasis. 


\section{References}

Abdel-Hamid, H, Ghoneimy, EA, AbdElaziz, MM, Helal, MA, 2014: Impact of penicillium canescens bioactive compound on some biological, histological and ultrastructural parameters of Biomphalaria alexandrina and Bulinus truncatus snails. Afr. J. Mycol. Biotec. 19 (2): 1-18.

Abdul Salam, JM, Michelson, EH, 1983: Schistosoma mansoni: Immunofluorescent detection of its antigen reacting with $B i$ omphalaria glabrata amoebocytes. Exp. Parasitol. 55(1):132-137.

Al-Sayed, E, Hamid, HA, Abu El Einin, HM, 2014: Molluscicidal and antischistosomal activities of methanol extracts and isolated compounds from Eucalyptus globulus and Melaleuca styphelioides. Pharm. Biol. 52, 6:698-705.

Anderson, RM, May, RM, 1985: Helminth infections of humans: mathematical models, population dynamics, and control. Adv. Parasitol., 24:1-10.

Babson, LA, 1965: Phenolphalein monophosphate methods for the determination of alkaline phosphatase. Clin. Chem. 11:78996.

Bakry, FA, Sakrane, AA, Ismail, NM, 2002: Molluscicidal effect of fungicide, herbicide and plant extract on some biological and physiological parameters in $\mathrm{Bi}$ omphalaria alexandrina. J. Egypt. Soc. Parasitol. 32, 3:821-35.

Barracco, MA, Steil, AA, Gargioni, R, 1993: Morphological characterization of the hemocytes of the pulmonate snail Biomphalaria tenagophila. Mem. Inst. Oswaldo Cruz 88, 1:73-83.

Cavalcanti, MGS, Filho, FC, Mendonca, AMB, Duarte, GR, Barbos, CCGS, et al, 2012: Morphological characterization of hemocytes from Biomphalaria glabrata and Biomphalaria straminea. Micron, 43:285-91.

Das, K, Thiagarajan, P, 2012: Mycobiosynthesis of metal nanoparticles. Int. J. Nanotechnol. Nanosci. 1:1-10.

Di, GL, Zhang, ZX, Ke, CH, Guo, JR, Xue, M, et al, 2011: Morphological characterization of the haemocytes of the ivory snail, Babylonia areolata (Neogastropoda: Buccinidae). J. Mar. Biol. Assoc. UK, 91:1489-97.
Domas, BT, 1975: Standards for total serum protein assays: A collaborative study. Clin Chemist, 21: 1159-66.

El-Hommossany, KS, El-Sherbibni, A, 2011: Impact of the photosensitizers' hematoporphyrin coated gold nanoparticles on Biomphalaria alexandrina snails. Open J. Anim. Sci. 1, 2:54-60.

Gawish, F, Mossalem, H, Abou El-Einin, H, 2008: Bioassay of the plant Callistemon citriun against Bulinus truncatus snails and their infection with Schistosoma haematobium. Egypt. J. Schist. Infect. Endem. Dis. 30:33-41.

Ghoneimy, EA, Abdel-Hamid, H, Morad, MH, Helal MA, 2014: Penicillium canescens bioactive compound as a molluscicidal and antischistosomal biocontrol agent. Afr. J. Mycol. Biotechnol. 19, 1: 123.

Gustafsson, JEC, 1976: Improved specificity of serum albumin determination and estimation of acute phase reactants by use of the bromocresol green reaction. Clin. Chem. 22:616-22.

Helmy, E, Mekawey, AAI, 2013: Mycobiosynthesis, optimization and characterization of silver nanoparticles. Afr. J. Mycol. Biotechnol. 18, 2:57-77.

Kambale, NA, Potdar, VV, 2010: Hematological analysis of Molluscan species Bellamya bengalensis and Lamiellidens marginalis. Biol. Forum Int. J. 2, 1:70-2.

Kamel, EG, Refaat, SW, El-Dafrawy, SM, Mohamed, AH, Mossalem, HS 2006: The effect of Schistosoma mansoni infection on Biomphalaria alexandrina haematocytes at ultra-structural level. Proceed. $4^{\text {th }}$ Int. Conf. Biol. Sci. (Zool.).

Kamel, EG, Refaat, SW, El-Dafrawy, SM, Mohamed, AH, Mossalem, HS, 2007: Toxicological effect of certain plants and synthetic molluscicides on ultrastructural changes in haemocytes of $B i$ omphalaria alexandrina. Egypt. J. Exp. Biol. (Zool.), 3:135.

Knight, JAS, Anderson, S, James, MR, 1972: Chemical basis of the sulphophosphovanilin reaction for estimating serum lipids. J. Clin. Chem. 18:199-202.

La atikainen, T, Peltonen, J, Nylander, P, 1973: Determination of estriol, estriol sulfate, progesterone and neutral steroid 
mono- and disulfates in umbilical cord blood plasma. J. Clin. Invest. 21, 3:347-59.

Lie, KL, Jeong, KH, Heyneman, D, 1987: Molluscan host reaction to helminthic infection. In: EJL Soulsby, Immune Responses in Parasitic Infections: Immunology, Immunopathology and Immunoprophilaxis. Vol. IV: Protozoa, Arthropods and Invertebrates, Chapter 7, CRC Press, Florida.

Mahendra, R, Alka, Y, Gade, A, 2009: Silver nanoparticles as a new generation of antimicrobials. Biotechnol. Adv. 27:76-83.

Mohamed, AH, 2011: Sublethal toxicity of Roundup to immunological and molecular aspects of Biomphalaria alexandrina to Schistosoma mansoni infection. Ecotox. Environ. Safe 74:754-80.

Mohamed, NZ, Aly, HF, 2014: Fenitrothion induced changes in amino acids profile of Biomphalaria alexandrina molluscan host of Schistosoma mansoni. Wld. J. Pharmac. Res. 3, 2:1648-61.

Moss, DW, 1984: Methods of enzymatic analysis, Bergmeyer, H.U. (ed.), Verlag Chemi. Weinheim, 4:92-106.

Mossalem, HS, Abdel-Hamid, H, ElShinnawy, NA, 2013: Impact of artemether on some histological and histochemical parameters in Biomphalaria alexandrina. Afr. J. Pharm. Pharmacol. 7, 31:2220-30,

Negm, H, Mansour, M, Saad, AH, Daoud, S, 1995: Defense mechanisms in adult and juvenile Biomphalaria alexanderina towards selective Schistosoma mansoni glycoproteins. J. Egypt. Immunol. 1:16376.

Noda, S, Loker, ES, 1989: Effect of infection with Echinostoma paraensei on the circulating hemocyte population of the snail host Biomphalaria glabrata. Parasitol. 98: 35-41.

Pagano, G, Iaccarino, M, De Biase, A, Meric, S, Warnau, M, et al, 2001: Factors affecting R6 fungicide toxicity on sea urchin fertilization as early development: roles of exposure routes and mixture components. Human Exp. Toxicol. 20, 8:40411.

Reitman, S, Frankel, S. (1957): A colorimetric method for determination of serum glutamic oxaloacetic and glutamic pyruvic transaminase. Am. J. Clin. Pathol. 28:5661.

Rizk, MZ, Metwally, NS, Hamed, MA, Mohamed, AM, 2012: Correlation between steroid sex hormones, egg laying capacity and cercarial shedding in Biomphalaria alexandrina snails after treatment with Haplophyllum tuberculatum. Exp. Parasitol. 132, 2:171-9.

Russo, J, Lagadic, L, 2004: Effects of environmental concentrations of atrazine on hemocyte density and phagocytic activity in the pond snail Lymnea stagnalis (Gastropoda, Pulmonata). Environ. Poll., 127:303-11.

Sastry, M, Ahmad, A, Khan, M, 2003: Biosynthesis of metal nanoparticles using fungi and actinomycete. Curr. Sci. 85:16270 .

Serrano, DR, Zanotti-Magalhães, EM, Magalhães, LA, de Carvalho, JF, 2002: The Influence of Hydrocortisone on Cellular Defence Mechanisms of Biomphalaria glabrata. Mem. Inst. Oswaldo. Cruz. Rio. de Janeiro. 97, 6:881-5.

Sharaf El-Din, AT, 2003: Effects of double infection with Echinostoma liei and Schistosoma mansoni on hemoglobin content and circulating haemocytes in the haemolymph of the host snail Biomphalaria alexandrina. Egypt. J. Schist. Infect. Endem. Dis. 25:41-52.

Sminia, T, Van der Knaap, WPW, 1987: Cells and molecules in molluscan immunology. Dev. Comp. Immunol. 11:17-28.

Sminia, T, 1981: Gastropods. In: NA, Ratcliffe, AE, Rowley (eds.), Invertebrate blood cells, vol. I. Academic Press, London.

Souza, S, Andrade, ZA, 2006: On the origin of the Biomphalaria glabrata haemocytes. Mem Inst Oswaldo Cruz. 101, 1:213-8.

Trinder, P, 1969: Determination of glucose in blood using glucose oxidase with an alternative oxygen acceptor. Amn. Clin. Biochem. 6:24-7.

White, BA, Erickson, MM, Stevens, SC, 1970: Determination of sGOT and sGPT enzymes; In: Chemistry for Medical Technologists. C. V. Mosby Company.

WHO, 1965: Molluscicide screening and evaluation. Bull. WHO 33:567-81. 


\section{Explanation of figures}

Fig. 1: Light microscopy photographs of Biomphalaria alexandrina hemocytes showing two types of hematocytes in the control; granulocytes (large [LG] and small [SG]) and hyalinocytes (Hy). Photgraphs showing hemocytes of B. alexandrina exposed for $24 \mathrm{~h}$ to $\mathrm{LC}_{10}$ of Paecilomyces variotii AgNPs (A-C), $\mathrm{LC}_{25}$ of P. variotii AgNPs (D-H), $\mathrm{LC}_{10}$ of Aspergillus niger AgNPs (I-K) and $\mathrm{LC}_{25}$ of A. niger AgNPs (L-N) (1000X).

Fig. 2: Light microscopy photographs of Biomphalaria alexandrina oocytes and sperms, control showing normal mature ovum and sperm (A), oocytes and sperms of B. alexandrina exposed for $24 \mathrm{~h}$ to $\mathrm{LC}_{10}$ of Paecilomyces variotii AgNPs (B-E) and $\mathrm{LC}_{25}$ of P. variotii AgNPs (F-I) (1000X).

Fig. 3: Light microscopy photographs of oocytes and sperms of Biomphalaria alexandrina exposed for $24 \mathrm{~h}$ to $\mathrm{LC}_{10}$ of Aspergillus niger AgNPs (A-C) and $\mathrm{LC}_{25}$ of A. niger AgNPs (D-G) (1000X).

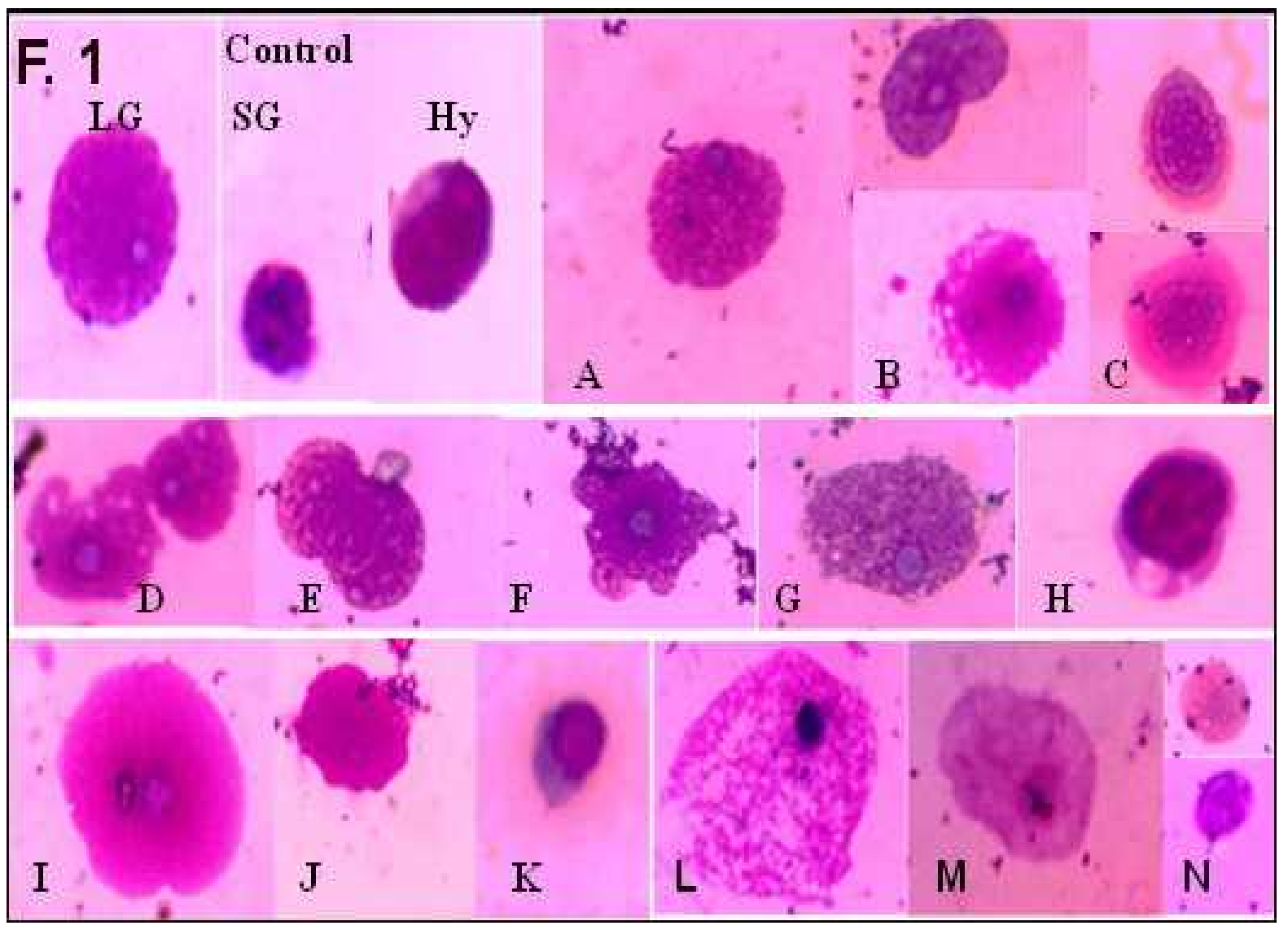




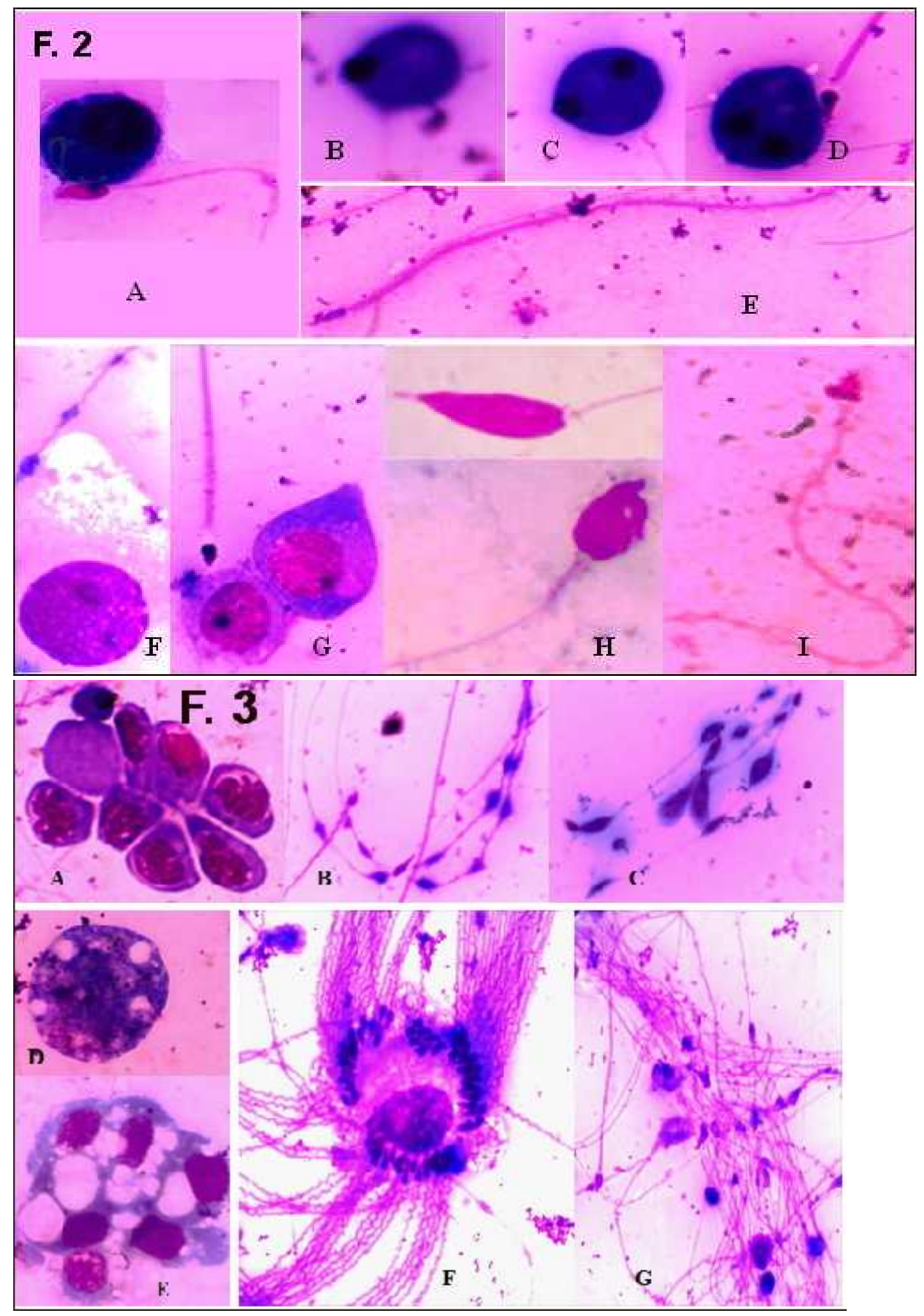

